\title{
The Gospel of Science
}

\author{
Raymond Downing ${ }^{a}$ \\ ${ }^{a}$ MD, Senior Lecturer, Department of Family Medicine, Moi University School of Medicine, Kenya
}

\begin{abstract}
Medical missionaries have always been a part of global health. One of their greatest potential assets as global health workers was that they carried with them a spiritual understanding of life. Although they didn't always realize it, the people they came to serve, especially in Africa, also functioned within a spiritual understanding of life. In the early $19^{\text {th }}$ Century, before medical science had much to offer, some of the medical missionaries were aware of this and recognized that their spirituality had something in common with people in Africa. However, as medical science grew in effectiveness, the role of spirituality in medicine began to diminish, even for medical missionaries themselves. By the early $20^{\text {th }}$ century, their spiritual understandings, while often still very strong in the religious realm, had been replaced by science in the medical realm. How did this come about?
\end{abstract}

\section{Introduction}

In 1803, Dr. Thomas Winterbottom, writing about superstition and "witchcraft" in West Africa, noted that West Africans "conceive that no death is natural or accidental, but . . . is the effect of supernatural agency," and commented on how strongly "is the notion of medicine being a supernatural art imprinted on the minds of the people on the western coast of Africa, that they look on every person who practices it as a witch . .."1 Many European visitors to Africa in the $19^{\text {th }}$ century used the word "witchcraft" promiscuously. In this text, Dr. Winterbottom seems to use the term almost interchangeably with "supernatural" - but the distinction is important. Africans then held - and mostly still hold - an understanding of the world as peopled with ancestors and spirits, and above them all, the Supreme Being. Those ancestors (the "living dead") and spirits maintain communication with people, often through dreams, diviners, and healers. ${ }^{2,3,4}$ This is the supernatural world to which Winterbottom referred. In addition, Africans understand that there are witches, separate from the diviners, mediums, and healers. Witchcraft is always evil, and witches are the enemies of life. In this sense, there are no witchdoctors; there are diviners who seek the causes of disease and healers who treat it - and there are witches who seek to do evil. ${ }^{2}$ They are not at all the same.

Despite calling this belief in supernatural agency "gross superstition," Winterbottom saw great potential value in African indigenous medicine. The entire second volume of his treatise is entitled "An Account of the Present State of Medicine Among the Natives of Sierra Leone," supporting his hope that Europeans could find new medicines there to add to their own remedies. ${ }^{5}$

Dr. David Livingstone also had a gentler view of these "superstitions." In his lectures at Cambridge University, published in 1858, he said that "most of the South African tribes have more or less clear ideas of a Supreme Being; but . . . they almost generally worship directly or indirectly the spirits of departed human beings, and

May 2015. Christian Journal for Global Health 2(1): 43-48. 
this more from fear than love ... It is a great step in advance towards a purer faith that they are not materialists; their very fears and superstitions are in the right direction." ${ }^{\prime \prime}$ As a Christian missionary, Livingstone well understood that Africans were already very religious.

Even at the end of the century, a few Europeans maintained this respect for African traditions and values. Dr. W.A. Elmslie, a medical missionary writing in 1899 , said that the traditional healer is "the visible and accessible agent of the ancestral spirits whom they believe in and worship." He then went on to dispassionately describe the characteristics and functions of these healers. To him, the implications of this African cosmology for evangelism were similar to what Livingstone noted:

... how is it that the materialistic writers and unbelieving critics of Missions affirm that the high moral and spiritual truths of Christianity cannot be grasped by them? . . . To talk of spiritual things is not to them an absurdity, much less is it impossible for them to conceive that such things may be ... The native lives continually in an atmosphere of spiritual things. ${ }^{7}$

Livingstone saw no conflict between spiritual, scientific, and commercial goals. He resigned from the London Missionary Society - but not from the Christian faith - half way through his 32 years in Africa. His goals then were clear: medical research, promoting commerce, and "diffusing a knowledge of Christ's Gospel, the best antidote for the wars of the world." ${ }^{8}$ His mission board had already let him know that they would be unable to undertake these sorts of projects, so Livingstone sought support elsewhere - and found it with the British government. Nevertheless, just before returning to Africa for his government-sponsored Zambezi exploration, he delivered his oft-quoted speech at Cambridge University in December, 1857, ending with his ap- peal: "I go back to Africa to try to make an open path for commerce and Christianity. Do you carry out the work which I have begun? I leave it to you."

This early merging of the science of the day with Christ's Gospel might be summarized in the motto of some mission hospitals even today, "We Treat, Jesus Heals." But more than this, these insights by $19^{\text {th }}$ Century doctors could have provided a foundation for all mission work, and the qualified respect for African cosmology would have benefitted all explorers and colonists, providing a basis for dialogue. But these were minority views, even among missionaries, and getting rarer as scientific successes pushed them aside.

In fact, as early as 1842 , the year after Livingstone first arrived in Africa, Dr. Daniel Macgowan gave an address on medical missions in New York. Macgowan was an American, shortly to become a medical missionary to China. Yet at age 28, he was clearly impressed with the potential of scientific medicine. Even before the germ theory of disease was clearly elucidated, and even longer before tropical medicine was called a specialty, Macgowan saw immense potential in this scientific medicine. Speaking of the physician, he said,

It is his province to assuage human suffering, in all its varieties and aggravations, and, in imitation of the Saviour, 'to heal all manner of diseases.' To extend the influence of science then, thus reduced to an ark of mercy, in the form of a profession, is obligatory upon us ... ${ }^{9}$

If the Bible was the ark of salvation, scientific medicine was the ark of mercy.

But, it was not just an ark of mercy. Macgowan, commenting on our responsibility as "civilized men" toward the "wretchedness" of the uncivilized, continued: "Medical science may thus become more than the fabled wand of Esculapius, and in its humble manner be like the brazen ser- 
pent raised by the prophet in the wilderness, mighty to save a nation from impending ruin." Scientific medicine, to him, could also bring salvation.

A few years later, the Edinburgh Medical Mission Society published a collection of Lectures on Medical Missions (1849) in which the confidence in scientific medicine was stated even more strongly. The Rev William Swan, who had been a missionary in Siberia, wrote on "The Importance of Medical Missions." He saw this importance as twofold:

I. The first is - the advancement of medical science in countries where ignorance in regard to it, and where a medical practice, founded on grossly erroneous principles, entails a fearful amount of suffering on the victims of disease in such countries.

II. The second and more direct object is - the promotion of evangelical truth in countries overrun with ignorance, idolatry, and superstition - the Medical Missionary rendering his practice as a physician and surgeon subservient to the promotion of that high object. The last of these is by far the most important object, and yet the first deserves the attention of the disciples of Him who went about continually doing good, healing all manner of disease among the people. $^{10}$

The first purpose of medical missions, he says, is the advancement of medical science; the second "more direct" and "most important" object is the promotion of "evangelical truth" in countries overrun with ignorance, idolatry, and superstition. In other words, the context of the more important object of evangelization is not merely idolatry or lack of Christian faith, but also "ignorance" and "superstition." Medical science is completely blended with the Gospel; scientific truth remains on a par with Gospel truth.
Then, toward the end of the $19^{\text {th }}$ century, especially after Europeans had fine-tuned their germ theory in the 1870s, European attitudes toward African understandings of disease changed significantly. In a book published in 1886, John Lowe describes the context of medical missions:

First of all, there is the lamentable ignorance existing in all heathen communities as to the cause, prevention, and cure of disease ... This ignorance is a fruitful source of superstition, and, consequently, one of the most effectual barriers in such lands to the uprooting of idolatrous rites and ceremonies. ${ }^{11}$

By the $20^{\text {th }}$ century, such attitudes were often reduced to contempt. Dr. Martin Edwards writes in 1909 about the work of the medical missionary:

The ignorance of the people of mission countries along the lines of municipal, household and social hygiene and regarding the cause and treatment of diseases is most deplorable and constitutes a great factor in the need for medical missionaries. Their superstitious, blind faith in fetishes and gods lays them open to the most rampant ravages of disease ... Their theories regarding health and disease are absurd and wholly directed by their superstitions. ${ }^{12}$

Dr. Neil Macvicar is a unique example of this gospel of science. He, like Dr. James Stewart, the missionary doctor who recruited him, "came early under the spell of Science,"13 a spell as strong as the witchcraft he was determined to eliminate and the Christianity that was responsible for him being in Africa. His profound belief in an empirical scientific approach informed both: he simply could not accept anything super- 
natural. "My belief," he wrote, "is that God reveals Himself, not by interruptions of the majestic order of His universe, but in and through that order, not through the abnormal but through the normal; that, though to our limited minds occurrences may not always be explicable, inherently there is nothing truly super-natural . . " $\mathrm{He}$ called Africans' spiritual explanations for disease "witchcraft" and "superstition" - and apparently felt the same about Christian beliefs such as miracles, the Incarnation, and the Resurrection. Those beliefs - or non-beliefs - caused him some difficulty in his early interviews with the mission board and were the reason he was dismissed from his first missionary assignment with the Church of Scotland in Blantyre, Malawi. ${ }^{14}$

Clearly, doctrinal beliefs such as the Resurrection have little to do with practicing medicine; Macvicar's biomedical practice was impeccable. However, practicing biomedicine in a culture very different from the one that developed it requires some understanding of that culture and of the concepts of disease there. As a Christian, Macvicar had access to a spiritual understanding that could have helped him understand his community. But, being "under the spell of Science," he had rejected aspects of that spirituality and forfeited an opportunity to have a deeper understanding of "witchcraft" and "superstition." Instead, he believed they were untrue and detrimental.

Of course, to hope that Christian spirituality could have infiltrated rational empiricism was perhaps too much to ask at this early stage of biomedicine. Science created the categories and assigned spirituality to the category of religion and then ignored it. When "Jesus Heals" married "We Treat," it was an unequal marriage; when biomedicine organized the family, it looked more like a divorce.

Consider Dr. Macvicar's occupational twin, Dr. Albert Cook. They arrived in Africa in the same year, 1896, both as British missionary doctors - Macvicar to South Africa, Cook to Uganda - and they both stayed for the rest of their lives. They did, however, differ theologically: whereas
Macvicar doubted anything supernatural, Cook maintained the evangelical dogma. But this evangelical fervor did not provide for him a window into African views of disease. He too bemoaned "the distressed native [whose] morass of misery [was] caused by unhygenic and superstitious surroundings that engulfs so many of them." And he had little patience with African concepts of disease. ${ }^{15}$ Cook did not draw on the spiritual basis of his own life to try and understand African spirituality.

Both Macvicar and Cook divorced the spiritual side of life from medicine. The difference was that after the divorce, Macvicar sent the supernatural packing, whereas Cook held on to it as a 'kept woman' in the Protestant Club. But kept isolated or sent away, they both lost the opportunity to understand spiritual Africa.

Then, in the midst of this contempt, we find the reflections of Dr. Albert Schweitzer, winner of the 1952 Nobel Peace Prize. Early in his sojourn in Africa, reflecting on what he had observed in the church on his mission station, he wrote,

But now, how far does the negro, as a Christian, really become another man? At his baptism he has renounced all superstition, but superstition is so woven into the texture of his own life and that of the society in which he lives, that it cannot be got rid of in twenty-four hours; he falls again and again in big things as in small. I think, however, that we can take too seriously the customs and practices from which he cannot set himself entirely free; the important thing is to make him understand that nothing no evil spirit - really exists behind his heathenism. ${ }^{16}$

For more than a century, Europeans had been trying to come to grips with "the other" in Africa - the people, the customs, and the cosmology, including its "germ theories" which the 
Europeans called superstition and witchcraft. Their struggles had ranged from respect to contempt, and now Schweitzer introduces a more modern approach. We need not worry about this whole African cosmology, he said, because not only is there no real evil there, "nothing really exists behind" it. Schweitzer took the final step beyond the divorce of "Jesus Heals" and "We Treat": in separating biomedical treatment from spiritual healing, he chose "We Treat" and killed the other.

Medical missions had common ground with African cosmology: both were rooted in spirituality. But most medical missionaries were not interested in comparing cosmologies; they had come to bring the Christian gospel and western medicine, not explore their own assumptions. In opting to only give and not receive, they let go of one of their most valuable means of understanding and learning from Africans. They were not interested in evaluating the scientific method according to a spiritual world view; they were content to maintain the duality of "We treat, Jesus heals."

It doesn't need to be this way. Most African patients maintain their spiritual cosmology and still selectively use the offerings of medical science. Many African healthcare providers maintain the balance as well. There is no inherent contradiction. Yet global health research is currently focused on how the latest scientific medical advances of the west can be applied in Africa. It may be time to return to what Winterbottom and Livingstone and Elmslie recognized, that there is value in traditional African understandings. Perhaps our Christian spirituality can enable us to see this African spirituality and, as a result, begin to redirect global health research and practice. We have, until now, been researching secular western approaches to healing. With our spiritual background, might we also be wellplaced to research healing approaches based on traditional spiritual values?

But more than this: might there be an opportunity here to re-examine our own spirituality, to see ourselves as African healers might see us?
How deeply do we believe that God is still involved in this world? Christians in the middle ages believed that "the birthing power of nature was rooted in the world's being contingent on the incessant creative will of God." ${ }^{17}$ This is a sentiment consistent with the West African proverbial question "What is not sacred?" Have we separated the science/treatment part of medical missions from the gospel/healing part, where the healing part is sacred but the treating part is not? Can we be reminded by Africans of the incessant creative will of God in the world? Can we relearn from Africa that everything is spiritual? $?^{3}$

\section{References}

1. Winterbottom T. An account of the native Africans in the neighborhood of Sierra Leone. vol 1. London: C Wittingham; 1803. Available from: https://archive.org/details/accountofnativea01wint

2. Magesa L. African religion: the moral traditions of abundant life. Maryknoll, NY: Orbis Books; 1997. [p. $161 \mathrm{ff} .$.

3. Magesa L. What is not sacred? African spirituality. Mayknoll, NY: Orbis Books; 2013.

4. Mbiti J. African religions and philosophy. Nairobi, East African Educational Publishers; 1969.

5. Winterbottom T. An account of the Native Africans in the neighborhood of Sierra Leone. vol 2. London: C Whittingham; 1803. Available from:

https://archive.org/details/accountofnativea02wint

6. Livingstone D. Dr. Livingstone's Cambridge lectures. Monk, W, editor. Cambridge: Deighton, Bell, and Co; 1858. Available from: https://archive.org/details/cambridgelecture00liviuoft

7. Elmslie WA. Among the wild Ngoni. New York: Fleming H. Revell; 1899. Available from: https://archive.org/details/amongwildngonibe00elms

8. Gelfand M. Livingstone the doctor: his life and travels. Oxford: Basil Blackwell; 1957. [p. 121-5]

9. Macgowan DJ. Claims of the missionary enterprise on the medical profession. New York: William Osborn; 1842. Available from: https://archive.org/details/62740930R.nlm.nih.gov 
10. Swan W. The importance of medical missions. in Edinburgh Medical Missionary Society. Lectures on medical missions. Edinburgh: Sutherland and Knox; 1849. p 87-134. Available from:

https://archive.org/details/lecturesonmedic00socigoog

11. Lowe J. Medical missions: their place and power. New York: Fleming H. Revell; 1886. Available from: https://archive.org/details/medicalmissionst00lowe

12. Edwards MR. The work of the medical missionary: eight outline studies. New York: Student Volunteer Movement; 1909. Available from: https://archive.org/details/workmedicalmiss00edwago og

13. Wells J. Stewart of Lovedale: the life of James Stewart. London: Hodder and Stoughton; 1909. Available from:

https://archive.org/details/stewartlovedale00wellgoog

14. Macvicar N. Believing in God. [1946] quoted in Lunde MJ. North meets South in medical missionary work: Dr. Neil Macvicar, African belief, and Western reaction. South African Historical Journal. 2009;61(2):336-56. http://dx.doi.org/10.1080/02582470902859666

15. Cook A. quoted in White L. They could make their victims dull: genders and genres, fantasies and cures in Colonial Southern Uganda. The American Historical Review, 1995 December;100(5): 1379-1402. http://dx.doi.org/10.2307/2169863

16. Schweitzer A. On the edge of the primeval forest: experiences and observations of a doctor in Equatorial Africa. London: A\&C Black, Ltd.; 1924. Available from: https://archive.org/details/cu31924029349788

17. Illich I. Brave new biocracy: health care from womb to tomb. New Perspectives Quarterly. Winter 94;11(1):4-13. Available from http://brandon.multics.org/library/Ivan\%20Illich/again st_life.html

Peer Reviewed

Competing Interests: None declared.

Correspondence: Raymond Downing, Moi University School of Medicine, Kenya. armdown2001@yahoo.com

Cite this article as: Downing R. The gospel of science. Christian Journal for Global Health (May 2015), 2(1): 43-48.

(C) Downing $\mathrm{R}$ This is an open-access article distributed under the terms of the Creative Commons Attribution License, which permits unrestricted use, distribution, and reproduction in any medium, provided the original author and source are properly cited. To view a copy of the license, visit http://creativecommons.org/licenses/by/3.0/ 